\title{
The Influence of Electronic and Steric Factors on the Coordination and on the Cluster Breakdown of Polynuclear Ruthenium Carbonyl Compounds
}

\author{
KEES VRIEZE, GERARD VAN KOTEN and LEENDERT H. STAAL \\ Anorganisch Chemisch Laboratorium, J. H. van't Hoff Instituut, University of Amsterdam, Nieuwe Achtergracht 166, 1018 WV \\ Amsterdam, The Netherlands
}

Received February 5, 1982

\section{Summary}

In this paper the coordination chemistry of $\alpha$ diimines $R-N=C\left(R^{\prime}\right)-\left(R^{\prime \prime}\right)-C=N R$ is discussed in relation to the steric and electronic properties of the $\alpha$-diimine ligands. It is shown that the steric properties of $R$ strongly determine the type of coordination which may range from $2 e, 4 e$, 6e to 8 donor bonding. In the cases of $2 e$ and $4 e$ donor bonding the lone pairs of the $N$ atoms are involved in coordination, while for $6 e$ and $8 e$ donor bonding the involvement of $\pi-C=N$ bonds was also observed, which leads to metal $-\eta^{2}-C=N$ interaction. The type of coordination further also influences the size of the cluster formed c.g. in reactions of $\left[\mathrm{Ru}_{3}(\mathrm{CO})_{12}\right]$ with $R-D A B$. It has been noted that the size of the cluster decreases with increasing branching of the $C^{\alpha}$ and $C^{\beta}$ atoms on the $R$ group. Finally, chemical activation of coordinated $\alpha$-diimine ligands is discussed. It has been found that the $\eta^{2}$-bonded imine groups are particularly suitable for further reactions with double-bonded systems such as imine and alkyne groups, which in the case of alkynes leads to catalytic formation of benzenes only in a completely regiospecific manner.

\section{Introduction}

The 1,4-disubstituted 1,4-diaza-1,3-butadienes $\mathrm{RN}=\mathrm{CR}^{\prime}-\mathrm{CR}^{\prime \prime}=\mathrm{NR}^{*}$ are of increasing interest because of their great variety of possible coordination modes [1]. The versatility is largely due to $(i)$ the flexibility of the $\mathrm{N}=\mathrm{C}-\mathrm{C}=\mathrm{N}$ skeleton, (ii) the strong $\sigma$-donor and $\pi$-acceptor properties, and (iii) the possibility of using many different $R, R^{\prime}$ and $R^{\prime \prime}$ substituents which allow the tuning of steric and electronic factors. The

\footnotetext{
*Abbreviated as $R-D A B\left\{R^{\prime}, R^{\prime \prime}\right\}$. If $R^{\prime}=R^{\prime \prime}=H$ the ligand name will be shortened to R-DAB.
}

$\alpha$-diimines may bind as $2 \mathrm{e}, 4 \mathrm{e}, 6 \mathrm{e}$ and $8 \mathrm{e}$ donor ligands (Fig. 1). In the 2e-bonding mode the diimine is bonded as a monodentate, via onc $\mathrm{N}$-atom. In the 4e-bonding situation the ligand may be bonded as a chelate or as a ligand bridging two metal atoms. For both cases the ligand uses both $\mathrm{N}$-atoms for bonding. In addition, it is now well established that the $\pi$-bonds of the imine groups may also be used for bonding to a metal atom [1]. In this way the $\alpha$-dimines may behave as $6 \mathrm{e}-$ or $8 \mathrm{e}$-donor ligand. We may therefore note that the $\alpha$-diimine ligand loosely resembles the $\mathrm{CO}$ or the $\mathrm{N}_{2}$ ligand, which are also able to use $2 \mathrm{e}, 4 \mathrm{e}, 6 \mathrm{e}$ and $8 \mathrm{e}$ for coordination.

In our group we have investigated extensively not only the stereochemistry of metal diimine complexes, but also the possibility of chemically activating the metal coordinated $\alpha$-diimine ligand. We thereby hoped to be able to correlate the type of chemical activation with the bonding type.

In this paper we will discuss (i) the $\alpha$-diimines, (ii) the coordination modes of the $\alpha$-diimines, and (iii) the chemical activation of metal coordinated $\alpha$-diimines.

The subject has already been reviewed in short in reference [1], and will be treated extensively in a chapter of a future edition of 'Advances in Organometallic Chemistry' (Ed. F. G. A. Stone) [2] .

\section{The 1,4-Diaza-1,3-butadiene Ligand}

Determination of the structure of $\mathrm{c}-\mathrm{Hex}-\mathrm{N}=$ $\mathrm{CH}-\mathrm{CH}=\mathrm{N}-\mathrm{c}-\mathrm{Hex}(\mathrm{c} \cdot \mathrm{Hex}-\mathrm{DAB})$ in the solid state by $\mathrm{X}$-ray crystallographic structure analysis showed a flat $\mathrm{N}=\mathrm{C}-\mathrm{C}=\mathrm{N}$ skeleton in the $E$-s-trans- $E$ conformation [3] with $\mathrm{C}-\mathrm{C}$ and $\mathrm{C}=\mathrm{N}$ distances which are completely compatible with a single $\mathrm{C}-\mathrm{C}$ bond and double $\mathrm{C}=\mathrm{N}$ bonds (i.e. 1.4571(23) $\AA$ and $1.2576(22)$ $\AA$ resp.). In solution the R-DAB compound exists predominantly in the $E$-s-trans- $E$ conformation with a dihedral $\mathrm{N}=\mathrm{C}-\mathrm{C}=\mathrm{N}$ angle lying between 90 and 
$\sigma-N \quad 2 e$

$\sigma-N \quad 2 e$

$$
\begin{aligned}
& \left|\mathrm{PdCl}_{2}\left(\mathrm{PPh}_{3}\right)(\mathrm{t}-\mathrm{Bu}-\mathrm{DAB})\right| \\
& x \text {-ray }[13]
\end{aligned}
$$

$\sigma, \sigma-N, N^{\prime} 4 e$

$\left[P t C I_{2}\left(\eta^{2}\right.\right.$-styrene $\left.)(t-B u-D A B)\right]$

x-ray [19]

$$
\sigma-N, \sigma-N^{\prime} \quad 2 e .2 e
$$

$\left[\left\{\mathrm{PtCl}_{2}\left(\mathrm{PBu}_{3}\right)\right\}_{2}(\mathrm{t}-\mathrm{Bu}-\mathrm{DAB})\right]$

$x-$ ray $[10,19]$

$\sigma-N \cdot \mu^{2}-N^{\prime} \eta^{2}-C N^{\prime} \quad 6 e$

$\left[\mathrm{Fe}_{2}(\mathrm{CO})_{6}(\mathrm{t}-\mathrm{Bu}-\mathrm{DAB})\right]$

$\mathrm{x}$-ray [31]

$$
\begin{gathered}
\sigma-N, \sigma-N^{\prime}, \eta^{2}-C N, \eta^{2}-C N^{\prime} 8 e \\
{\left[R_{2}(C O){ }_{4}\left(\mu^{2}-\text { acetylene }\right)-\sigma, a-\eta^{2}, \eta^{2}-\right.} \\
(i-\operatorname{Pr}-\mathrm{DAB})] \text { x-ray }[35-37]
\end{gathered}
$$

Fig. 1. Various coordination modes of R-DAB ligands.

$140^{\circ}$ [4]. The gas phase study of $t-B u-D A B$ showed the presence of a small amount of the s-trans conformation, while the most abundant conformation appeared to be the gauche conformation with a torsion of about $65^{\circ}$ from the $s$-cis form $[5,6]$.

In solution the s-cis form is destabilized about $20-28 \mathrm{~kJ} / \mathrm{mol}$ with respect to the s-trans form [5-8].

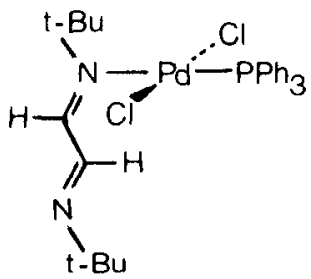<smiles>CC(=O)I(C)P1(Cl)(Cl)N(C(C)(C)C)C=CN1C(C)(C)C</smiles>

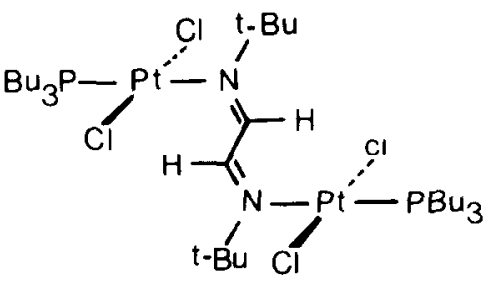

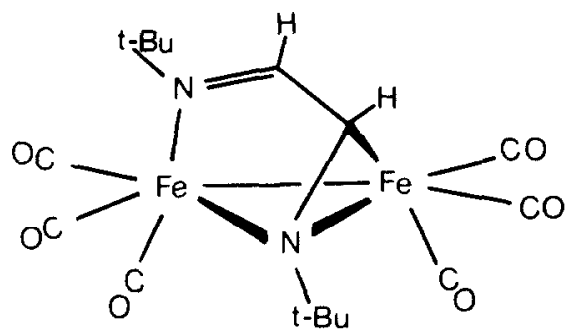

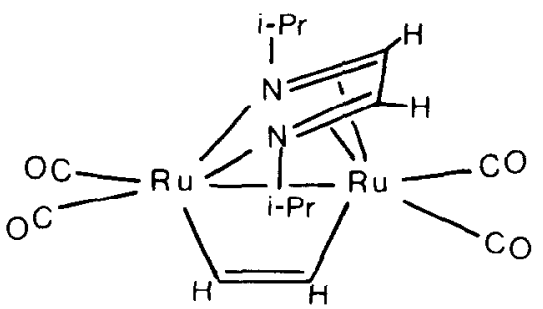


bonding mode the ligand is in the $E-s-c i s-E$ conformation $\left(\sigma, \sigma \cdot \mathrm{N}, \mathrm{N}^{\prime}\right.$ chelate). The $6 \mathrm{e}\left(\sigma \cdot \mathrm{N}, \mu_{2} \cdot \mathrm{N}^{\prime}\right.$, $\left.\eta^{2}-\mathrm{CN}^{\prime}\right)$ and $8 \mathrm{e}\left(\sigma-\mathrm{N}, \sigma-\mathrm{N}^{\prime}, \eta^{2}-\mathrm{CN}, \eta^{2}-\mathrm{CN}^{\prime}\right)$ bonding modes are characterised by the involvement of one $\pi-\mathrm{C}=\mathrm{N}$ and two $\pi-\mathrm{C}=\mathrm{N}$ bonds respectively, in addition to the lone pairs on the $\mathrm{N}$-atoms. In both cases the conformations range from gauche to planar $E-s-c i s-E$.

\section{a. Monodentate Bonded $R-D A B(\sigma-N ; 2 e)$}

The monodentate bonding fashion of R-DAB has only been observed for square planar $\mathrm{d}^{8}$-complexes (e.g. $\mathrm{Pd}^{\mathrm{II}}, \mathrm{Pt}^{\mathrm{II}}$ and $\mathrm{Rh}^{\mathrm{I}}[9-12]$ ). The crystal structure of trans-[( $\left.\left.\mathrm{Ph}_{3} \mathrm{P}\right) \mathrm{PdCl} \mathrm{Cl}_{2}(\mathrm{t}-\mathrm{Bu}-\mathrm{DAB})\right]$ has been determined [13] (Fig. 1). Of interest is that $\mathrm{H}^{\beta}$ is situated above the coordination plane close to the $\mathrm{Pd}^{\mathrm{II}}$ atom. This conformation is retained in solution as shown by the anomalously low field ${ }^{1} \mathrm{H}$ NMR chemical shift of this hydrogen atom. At room temperature the metal interchanges its coordination position intramolecularly. This process must involve $E$ to $Z$ inversion at the non-coordinated $\mathrm{N}$-atom and rotation around the central $\mathrm{C}-\mathrm{C}$ bond. It is assumed that the intermediate is a five-coordinate species with the R-DAB ligand in the $E-s-c i s-E$ conformation [12]. The analogous $\mathrm{Pt}$ compounds trans-[PtCl$\left(\mathrm{PPh}_{3}\right)$ (R-DAB)] [9] also contain $\sigma$-N monodentate R-DAB groups. However, when $\mathrm{PPh}_{3}$ is replaced by an olefin, five-coordinate complexes [PtCl $2\left(\eta^{2}\right.$-olefin $\left.)(\mathrm{R}-\mathrm{DAB})\right]$ are obtained in which the R-DAB is in the chelate form and coplanar with the $\mathrm{Pt}-\eta^{2}$-olefin unit $[12$, $14,15-17]$. It has been suggested that the better $\pi$-backbonding ability of the olefin is compensating for the larger charge density in going from the monodentate ( $2 \mathrm{e}$ ) to chelate bonding (4e) for the R-DAB ligand. In addition to electronic factors steric factors are also important when comparing the various coordination types, since for example the five-coordinate complex $\left[\mathrm{RhCl}(\mathrm{CO})_{2}(\mathrm{R}-\mathrm{DAB})\right]$ is stabilized relative to four-coordinate ionic [Rh(CO) $2(\mathrm{R}-\mathrm{DAB})]$ $\left[\mathrm{RhCl}_{2}(\mathrm{CO})_{2}\right]$ (with chelating R-DAB) and the dinuclear $\left[\left\{\mathrm{RhCl}(\mathrm{CO})_{2}\right\}_{2}(\mathrm{R} \cdot \mathrm{DAB})\right]$ (with bridging $\mathrm{R}-\mathrm{DAB})$ if $\mathrm{R}$ contains a triply branched $\mathrm{C}^{\alpha}$ atom (e.g. t-Bu) [18]. Similarly the (kinetic) stability of five coordinate $\left[\mathrm{PtCl}_{2}\left(\eta^{2}\right.\right.$-olefin $\left.)(\mathrm{R}-\mathrm{DAB})\right]$ with chelating R-DAB was enhanced when the branching of $\mathrm{R}$ was increased from double to triple for $\mathrm{C}^{\alpha}$ and from single to double for $C^{\beta}[14]$.

\section{b. Bridging R-DAB Ligands $(\sigma-N, \sigma-N ; 2 e+2 e)$}

An X-ray structure determination of $\left[\left\{\mathrm{PtCl}_{2}\right.\right.$ $\left.\left.\left(\mathrm{PBu}_{3}\right)\right\}_{2}(\mathrm{t}-\mathrm{Bu}-\mathrm{DAB})\right]$ has established the bridging mode of $t-B u-D A B$, which itself is planar with both $\mathrm{H}^{\beta}$ imine $\mathrm{H}$ atoms situated above a planar coordination plane close to a Pt atom (Fig. 1) $[10,19]$. This structure was also retained in solution, as evidenced by the anomalously low field shift of $\mathrm{H}^{\beta}$ in the ${ }^{1} \mathrm{H}$ NMR spectrum and by ${ }^{15} \mathrm{~N}$ and ${ }^{195} \mathrm{Pt}$ NMR spectra
[12]. In the previous section we have mentioned that the bridging bonding mode also occurs for $\mathrm{Rh}^{\mathrm{I}}$ complexes.

\section{c. Chelate Bonded $R-D A B\left(\sigma, \sigma-N, N^{\prime} ; 4 e\right)$}

The chelate bonding mode of the R-DAB ligand is very well established, being known since 1953 when Krumholz reported complexes of the type $\left[\mathrm{Fe}(\mathrm{Me}-\mathrm{DAB})_{3}\right] \mathrm{I}_{2}[19]$. Since then other groups have studied extensively the preparative methods, structural, bonding and chemical aspects of complexes containing chelated R-DAB ligands. Complexes have been isolated for many transition metals of the periodic system with electronic configurations ranging from $\mathrm{d}^{0}$ to $\mathrm{d}^{10}$, while also complexes have been formed with a number of post-transition and metal atoms e.g. $\mathrm{Cu}^{\mathrm{I}}[21], \mathrm{Zn}^{\mathrm{II}}[22], \mathrm{Al}^{\mathrm{III}}$ [23] .

The bonding of the chelating R-DAB ligand (4e) has been most extensively investigated for complexes $\left[\mathrm{M}(\mathrm{CO})_{4}(\mathrm{R}-\mathrm{DAB})\right](\mathrm{M}=\mathrm{Cr}, \mathrm{Mo}, \mathrm{W})[24-28]$. It can be concluded that there is extensive $\sigma$ and $\pi$ overlap in the planar five membered R-DAB ring. In particular there is strong $\pi$-backbonding between $\mathbf{M}$ and the chelated R-DAB ligand which increases in importance on going to higher electronic configuration i.e. $\mathrm{d}^{6}<\mathrm{d}^{7}<\mathrm{d}^{8}<\mathrm{d}^{9}[29,30]$.

\section{d. Bridging $R-D A B$ Ligands Bonded in a $\sigma-N, \mu^{2}-N^{\prime}$, $\eta^{2}-C=N^{\prime}(6 e)$ Fashion}

Frühauf et al. [32] reported the first compounds with the R-DAB ligand bonded as a 6e-donor ligand $\left(\sigma-\mathrm{N}, \mu^{2}-\mathrm{N}^{\prime}, \eta^{2}-\mathrm{C}=\mathrm{N}^{\prime}\right.$ ) (Fig. 1). The structure of $\left[\mathrm{Fe}_{2}(\mathrm{CO})_{6}(\mathrm{R}-\mathrm{DAB})\right](\mathrm{R}=\mathrm{c}-\mathrm{Hex})$ demonstrates that $2 \mathrm{e}$ are donated by the $\sigma-\mathrm{N}$ bonded $\mathrm{N}=\mathrm{C}$ group (which has a normal bond length of $1.260 \AA$ ) and $4 \mathrm{e}$ via the other $\mathrm{N}=\mathrm{C}$ group $(1.397 \AA)$. This last $\mathrm{N}=\mathrm{C}$ group (formally) donates $2 \mathrm{e}$ via $\eta^{2}-\mathrm{N}=\mathrm{C}$ bonding to one $\mathrm{Fe}$ atom and $2 \mathrm{e}$ through the bridging $\mathrm{N}$ atom. Characteristic is the increase in bond length of the $\eta^{2}$ bonded $\mathrm{N}=\mathrm{C}$ group to about $1.40 \AA$, which has also been observed for $\left[\mathrm{MnCo}(\mathrm{CO})_{6}(\mathrm{t}-\mathrm{Bu}-\mathrm{DAB})\right][32]$ and for $\left[\mathrm{Ru}_{2}(\mathrm{CO})_{4}(\mathrm{i}-\mathrm{Pr}-\mathrm{DAB})_{2}\right]$ [33]. The $6 \mathrm{e}$ bonding mode has also been found for $\left[\mathrm{Ru}_{2}(\mathrm{CO})_{6}(\mathrm{R}-\mathrm{DAB})\right]$ [33] and $\left[\mathrm{Os}_{2}(\mathrm{CO})_{6}(\mathrm{R}-\mathrm{DAB})\right]$ [34]. For all these complexes it has also been observed that the ${ }^{1} \mathrm{H}$ and ${ }^{13} \mathrm{C}$ NMR signals of the $\eta^{2}$ bonded ${ }^{1} \mathrm{H}{ }^{13} \mathrm{C}=\mathrm{N}$ units shift appreciably to higher fields, indicating strong $\pi$-backdonation into the $\pi^{*} \mathrm{~N}=\mathrm{C}$ levels which is compatible with the bond lengthening of the $\eta^{2}$. bonded $\mathrm{N}=\mathrm{C}$ groups $[32,34]$.

Of interest is that the $\sigma-\mathrm{N}, \mu^{2}-\mathrm{N}^{\prime}, \eta^{2}-\mathrm{C}=\mathrm{N}^{\prime}$ bonding mode is strongly destabilized when the imino $\mathrm{H}$ atoms are substituted by $\mathrm{CH}_{3}$ groups. Indeed, for the case of $\left.\left[\mathrm{MnCo}(\mathrm{CO})_{6}(\mathrm{R}-\mathrm{DAB})\{\mathrm{Me}, \mathrm{Me}\}\right)\right]$ only have we been able to isolate a compound with a R-DAB $\{\mathrm{Me}$, $\mathrm{Me}$; in the $6 \mathrm{e}$ bonding mode, and this could only be effected for $\mathrm{R}=$ cyclopropyl. 


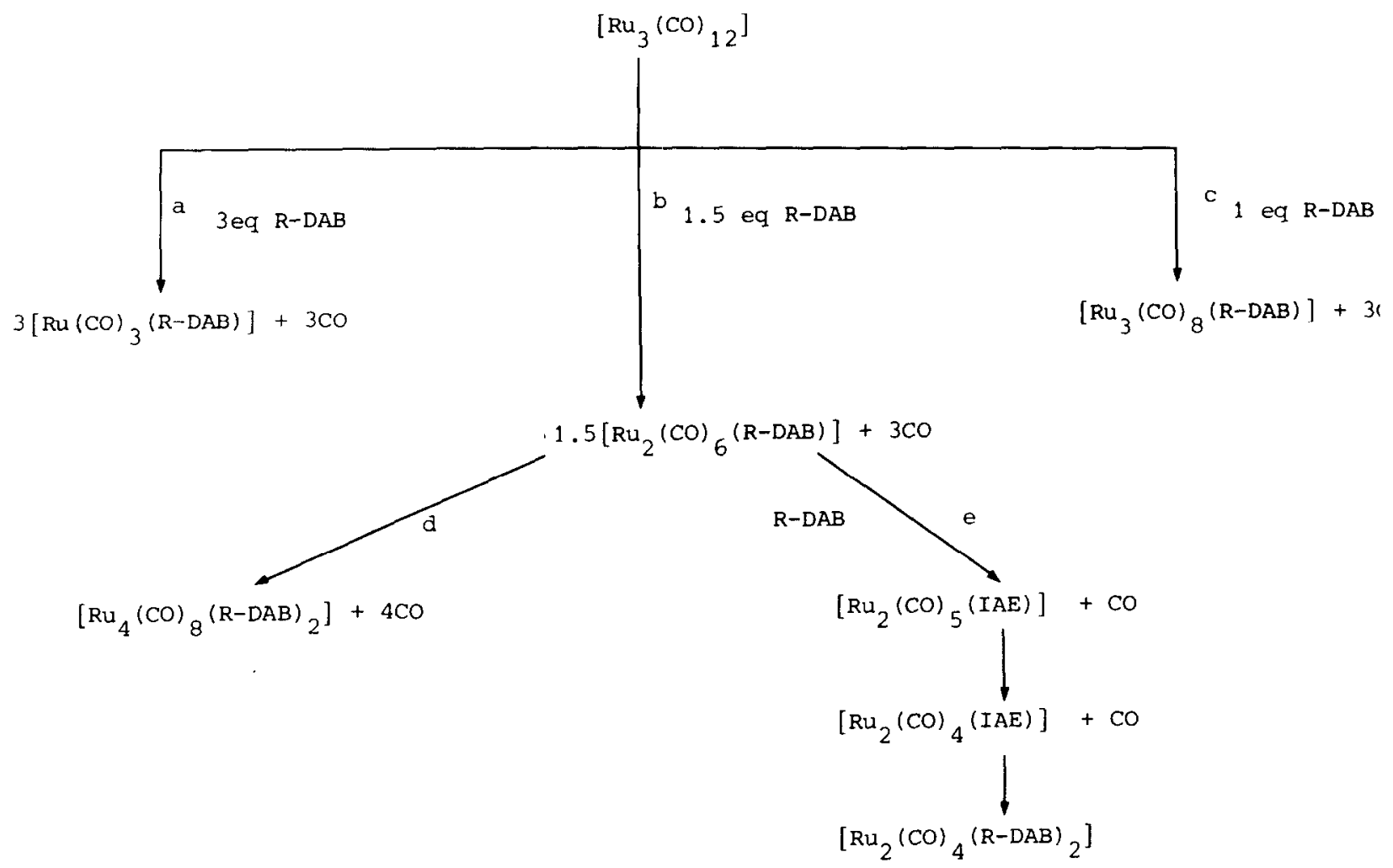

Fig. 2. Reactions of $\left[\mathrm{Ru}_{3}(\mathrm{CO})_{12}\right]$ with $\mathrm{R}-\mathrm{DAB}$ (see text).

In the following section we will discuss more extensively the formation of $\sigma-\mathrm{N}, \mu^{2}-\mathrm{N}^{\prime}, \eta^{2}-\mathrm{C}=\mathrm{N}^{\prime}$ bonded R-DAB groups as influenced by the electronic and steric features of the R-group.

e. Bridging R-DAB Ligands Bonded in a $\sigma-N, \sigma-N^{\prime}$, $\eta^{2}-C=N, \eta^{2}-C=N^{\prime}(8 \mathrm{e})$ Fashion

In Fig. 1 the compound $\left[\mathrm{Ru}_{2}(\mathrm{CO})_{4}\left(\mu^{2}-\mathrm{C}_{2} \mathrm{H}_{2}\right)(\mathrm{i}-\right.$ Pr-DAB)] contains a R-DAB ligand which is $\sigma \cdot \mathrm{N}$, $\sigma-\mathrm{N}^{\prime}, \eta^{2}-\mathrm{C}=\mathrm{N}, \eta^{2}-\mathrm{C}=\mathrm{N}^{\prime}(8 \mathrm{e})$ bonded to a $\mathrm{Ru}_{2}$ pair [35-37]. The complex is formed by the reaction of $\mathrm{HC}_{2} \mathrm{H}$ with $\left[\mathrm{Ru}_{2}(\mathrm{CO})_{6}(\mathrm{R}-\mathrm{DAB})\right]$.

The reaction proceeds very likely via an intermediate complex $\left[\mathrm{Ru}_{2}(\mathrm{CO})_{5}(\mathrm{R}-\mathrm{DAB})\left(\mathrm{HC}_{2} \mathrm{H}\right)\right]$ in which the acetylene is inserted into the metal- $\eta^{2}$. $\mathrm{C}=\mathrm{N}$ linkage of the original $\left[\mathrm{Ru}_{2}(\mathrm{CO})_{6}(\mathrm{R}-\mathrm{DAB})\right]$ complex (see later discussion on insertion of alkynes).

Other examples of 8e-bonding have been found for $\left[\mathrm{Ru}_{4}(\mathrm{CO})_{8}(\mathrm{i}-\mathrm{Pr}-\mathrm{DAB})_{2}\right] \quad[36,38]$ and for $\left[\mathrm{Mn}_{2}\right.$ $\left.(\mathrm{CO})_{6}(\mathrm{Me}-\mathrm{DAB}\{\mathrm{Me}, \mathrm{Me}\})\right]$ [39]. For all cases the $\mathrm{C}=\mathrm{N}$ bond distances have lengthened to about 1.40 to $1.45 \AA$, while the central $\mathrm{C}-\mathrm{C}$ bond has shortened to around 1.40 to $1.42 \AA$. These effects can be explained by assuming population of the first LUMO of the $\mathrm{N}=\mathrm{C}-\mathrm{C}=\mathrm{N}$ skeleton, which is antibonding in $\mathrm{C}=\mathrm{N}$ and bonding in $\mathrm{C}-\mathrm{C}$ [1]. In addition to the changes in the bond distances it has been observed that the ${ }^{1} \mathrm{H}$ and ${ }^{13} \mathrm{C}$ NMR signals of the ${ }^{1} \mathrm{H}^{13} \mathrm{C}=\mathrm{N}$ imine units shift to high field, although not as much as has been noted for the $\left[\mathrm{M}_{2}(\mathrm{CO})_{6}(\mathrm{R}-\mathrm{DAB})\right] \mathrm{com}$ plexes which contain one $\eta^{2}-\mathrm{C}=\mathrm{N}$ bonded group. Comparison of the chemical shift trends show that they are a good diagnostic tool for determining the type of bonding. For example the ${ }^{1} \mathrm{H}$ NMR shifts lie in the range of 3.3 to $5.5 \mathrm{ppm}$ for $\sigma-\mathrm{N}, \mu^{2}-\mathrm{N}^{\prime}$, $\eta^{2}-\mathrm{C}=\mathrm{N}^{\prime}(6 \mathrm{e})$ bonding and in the range of 5.9 to $6.6 \mathrm{ppm}$ for $\sigma-\mathrm{N}, \sigma-\mathrm{N}^{\prime}, \eta^{2}-\mathrm{C}=\mathrm{N}, \eta^{2}-\mathrm{C}=\mathrm{N}^{\prime}(8 \mathrm{e})$ bonding $[29,37,40]$. The ${ }^{1} \mathbf{H}$ NMR chemical shifts for the imine $\mathrm{H}$ atoms of the free ligands and of nitrogen bonded imine groups of the R-DAB ligands are found at considerably lower fields i.e. between 8 and $10 \mathrm{ppm}$.

\section{The Influence of Steric and Electronic Factors on the Formation of Ruthenium Clusters}

We have already seen how strongly the branching of the R-substituent may influence the relative stability of four- versus five-coordinate structures (see 4a).

We will now discuss the influence of the branching of the $\mathrm{R}$ group on the type of products formed in the reaction of $\left[\mathrm{Ru}_{3}(\mathrm{CO})_{12}\right]$ with $\mathrm{R}-\mathrm{DAB}[38]$. 


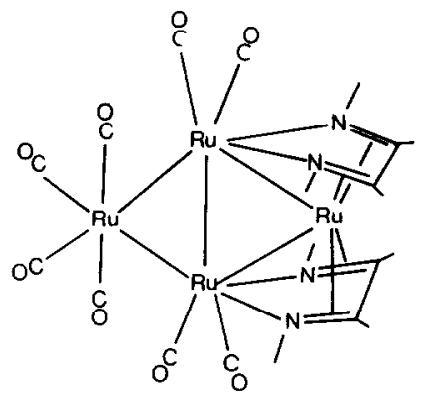

Fig. 3. Structure of $\left[\mathrm{Ru}_{4}(\mathrm{CO})_{8}(\mathrm{R}-\mathrm{DAB})_{2}\right]$.

A tentative reaction scheme is shown in Fig. 2 .

The product formed is largely dependent on the branching at $\mathrm{C}^{\alpha}$ and at $\mathrm{C}^{\beta}[1,38]$. We may rationalize these findings by considering the influence of these branchings on the blocking of the approach of metal atoms to the $\pi$-bonds of the imine groups. For example, when we bring the $\mathrm{RN}=\mathrm{C}-\mathrm{C}=\mathrm{NR}$ group in the planar $E$-s-cis- $E$ conformation by chelation to a metal atom then the $\pi$-bonds at both sides of $\mathrm{M}-\mathrm{N}=$ $\overline{\mathrm{C}-\mathrm{C}=\mathrm{N}}$ skeleton may become blocked towards attack on the $\pi$-bonds, when we use R-groups which are doubly branched at $\mathrm{C}^{\alpha}$ and $\mathrm{C}^{\beta}$ (i.e. $\mathrm{R}=2,4,6$-Mes; $2,6-\mathrm{Xyl} ; \mathrm{i}-\mathrm{Pr}_{2} \mathrm{CH}$ ). In this way it is virtually impossible to coordinate further metal atoms and as a result $\left[\mathrm{Ru}(\mathrm{CO})_{3}(\mathrm{R}-\mathrm{DAB})\right]$ is the final product (route (a) of Fig. 2). However, by the use of $R=n$-Pent or $i$ $\mathrm{Bu}$ (i.e. singly branched at $\mathrm{C}^{\alpha}$ and doubly branched at $C^{\beta}$ ) we may see that the $\mathrm{M}-\mathrm{N}=\mathrm{C}-\mathrm{C}=\mathrm{N}$ plane is open at one side for metal attachment. In this case $\left[\mathrm{Ru}_{3}(\mathrm{CO})_{8}(\mathrm{R}-\mathrm{DAB})\right]$ is preferentially formed (route $c$ of Fig. 2), while the R-DAB ligand behaves as a $\sigma-\mathrm{N}, \sigma-\mathrm{N}^{\prime}, \eta^{2}-\mathrm{C}=\mathrm{N}, \eta^{2}-\mathrm{C}=\mathrm{N}^{\prime}(8 \mathrm{e})$ donor ligand, since the imino $\mathrm{H}$ atoms absorb at 5.86 and $5.89 \mathrm{ppm}$ for $\mathrm{R}=\mathrm{i}-\mathrm{Bu}$ and $\mathrm{n}$-Pent respectively [38] .

In the cases of $\mathrm{R}=\mathrm{i}-\mathrm{Pr}, \mathrm{c}-\mathrm{Hex}$ or $\mathrm{Ar}$, the $\mathrm{R}$ group is doubly branched at $\mathrm{C}^{\alpha}$ and singly branched at $C^{\beta}$. For these $R$ groups we see first the formation of $\left[\mathrm{Ru}_{2}(\mathrm{CO})_{6}(\mathrm{R}-\mathrm{DAB})\right]$ (route $\mathrm{c}$ of Fig. 2) with R-DAB in the $\sigma-\mathrm{N}, \mu^{2}-\mathrm{N}^{\prime}, \eta^{2}-\mathrm{C}=\mathrm{N}^{\prime}(6 \mathrm{e})$ donor mode, but there is clearly still sufficient room for $8 \mathrm{e}$ donor bonding, since $\left[\mathrm{Ru}_{4}(\mathrm{CO})_{8}(\mathrm{R}-\mathrm{DAB})_{2}\right]$ (Fig. 3, route d of Fig. 2) [38] is formed almost quantitatively from $\left[\mathrm{Ru}_{2}(\mathrm{CO})_{6}(\mathrm{R}-\mathrm{DAB})\right]$ by further heating [38]. If $\mathrm{R}=\mathrm{t}-\mathrm{Bu}$ (i.e. triply branched at $\mathrm{C}^{\alpha}$ ) then only $\left[\mathrm{Ru}_{2}(\mathrm{CO})_{6}(\mathrm{R}-\mathrm{DAB})\right]$ is formed [38], clearly indicating the delicate roles which the steric bulk and the branching of $\mathrm{R}$ play in stabilizing $6 \mathrm{e}$ versus $8 \mathrm{e}$-donor bonding of R-DAB. We may therefore conclude that increased branching of $\mathrm{R}$ at both $\mathrm{C}^{\alpha}$ and $\mathrm{C}^{\beta}$ decreases the tendency towards metal $-\eta^{2}-\mathrm{C}=\mathrm{N}$ bonding, while at the same time the cluster formation is increasingly hindered.

After this discussion on the role which $\mathbf{R}$ plays in the type of products formed in the reactions of $\left[\mathrm{Ru}_{3}(\mathrm{CO})_{12}\right]$ with $\mathrm{R}-\mathrm{DAB}$, we think it worthwhile

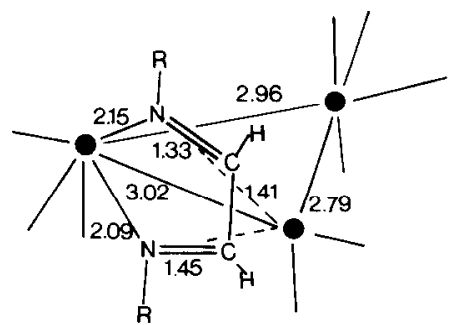

Fig. 4. Schematic structure of $\left[\mathrm{Ru}_{3}(\mathrm{CO})_{9}(\mathrm{c}-\mathrm{HexDAB})\right]$.

considering the mechanisms of the various reactions. Such a discussion is of course tentative, since little experimental evidence has been compiled as yet.

Naturally, the first step involves the reaction of $\left[\mathrm{Ru}_{3}(\mathrm{CO})_{12}\right]$ with R-DAB. Information about this step may be gleaned from the kinetic data obtained by HPLC measurements [41]. It was found that the reaction with $\mathrm{i}-\mathrm{Pr}-\mathrm{DAB}$ is first order in $\left[\mathrm{Ru}_{3}(\mathrm{CO})_{12}\right]$ and first order in the R-DAB ligand, the overall reaction having the order two. An unstable intermediate of the composition $\left[\mathrm{Ru}_{3}(\mathrm{CO})_{11}(\mathrm{R}-\mathrm{DAB})\right]$ or more probably $\left[\mathrm{Ru}_{3}(\mathrm{CO})_{10}(\mathrm{R}-\mathrm{DAB})\right]$ is formed in the rate determining step.

The reactions after this first step could not be studied so that we have to use more circumstantial evidence.

Therefore it is of interest to mention the formation of $\left[\mathrm{Ru}_{3}(\mathrm{CO})_{9}(\mathrm{c}-\mathrm{Hex}-\mathrm{DAB})\right]$ during the preparation of $\left[\mathrm{Ru}_{2}(\mathrm{CO})_{6}(\mathrm{c}-\mathrm{Hex}-\mathrm{DAB})\right]$ [42]. The $\mathrm{X}$-ray structural determination of the trinuclear complex shows an asymmetrically bonded c-Hex-DAB ligand which appears to be bonded more or less as an $\sigma-\mathrm{N}, \sigma-\mathrm{N}^{\prime}, \eta^{2}-\mathrm{C}=\mathrm{N}, \eta^{2}-\mathrm{C}=\mathrm{N}^{\prime}(8 \mathrm{e})$ donor ligand with $\mathrm{C}=\mathrm{N}$ bond lengths of 1.33 and $1.45 \AA$ (Fig. 4). The bond length of $1.45 \AA$ is compatible with extensive $\pi$-backbonding. The other $\mathrm{C}=\mathrm{N}$ bond is close to the $\eta^{2}$-bonded $\mathrm{C}=\mathrm{N}$ bond length of $1.36 \AA$ of $[\mathrm{MnCo}$ (CO) $\left.{ }_{6}(\mathrm{t}-\mathrm{Bu}-\mathrm{DAB})\right][32]$, but is also close to the longest bond lengths observed for $\sigma, \sigma-\mathrm{N}, \mathrm{N}^{\prime}$ (4e) bonded R-DAB ligands (e.g. [Ni(R-DAB $)_{2}$ ] [43, 35] and $[\mathrm{Mn}(\mathrm{R}-\mathrm{DAB})]_{2}[44]$, i.e. for electron rich metal compounds). We may therefore conclude that this c-Hex-DAB in $\left[\mathrm{Ru}_{3}(\mathrm{CO})_{9}(\mathrm{c}-\mathrm{Hex}-\mathrm{DAB})\right]$ donates between six to eight electrons to the $\mathrm{Ru}_{3}$ cluster. This is compatible with the $\mathrm{Ru}-\mathrm{Ru}$ distances of 3.02, 2.96 and $2.79 \AA$, which should be compared with the bond length of $2.854 \AA$ in $\left[\mathrm{Ru}_{3}(\mathrm{CO})_{12}\right.$ ] [46]. According to the rules of Wade [47] we would have expected approximately normal bond lengths for a $48 \mathrm{e}$ cluster i.e. if the R-DAB in $\left[\mathrm{Ru}_{3}(\mathrm{CO})_{9}(\mathrm{c}-\mathrm{Hex}-\right.$ DAB)] would behave strictly as a $\sigma-\mathrm{N}, \mu^{2}-\mathrm{N}^{\prime}, \eta^{2}$. $\mathrm{C}=\mathrm{N}^{\prime}(6 \mathrm{e})$ donor ligand. From the crystal structures, however, it is clear that the R-DAB ligand is donating more than $6 \mathrm{e}$ and so it is not surprising that the LUMO on the $\mathrm{Ru}_{3}$ cluster is populated, thereby 
causing bond lengthening of two of the three $\mathrm{Ru}_{2}$ pairs. An interesting conclusion emerging from these findings is that rearrangement of an R-DAB ligand from a $6 \mathrm{e}$ to an $8 \mathrm{e}$ bonding mode, or for that matter also from a $2 \mathrm{e}$ to a $4 \mathrm{e}$ or from a $4 \mathrm{e}$ to a $6 \mathrm{e}$ bonding mode, may cause cluster breakdown.

At first sight we might therefore conclude that the cluster breakdown from $\mathrm{Ru}_{3}$ to $\mathrm{Ru}_{2}$ and $\mathrm{Ru}$ might proceed in such a way, while the branching of the $\mathrm{R}$ groups determines which type of compound is the end product. On the other hand we have now obtained evidence that in many cases reactions of $\left[\mathrm{Ru}_{3}(\mathrm{CO})_{12}\right]$ with $\mathrm{R}-\mathrm{DAB}$ leads first in a very fast reaction to the formation of $\left[\mathrm{Ru}(\mathrm{CO})_{3}(\mathrm{R}-\mathrm{DAB})\right]$, which, when unstable for small $R$ groups, further reacts with $\left[\mathrm{Ru}_{3}(\mathrm{CO})_{12}\right]$ to give $\mathrm{Ru}_{3}$ and $\mathrm{Ru}_{2}$ species [42]. Since we know too little at present it is not profitable to discuss in more detail the breakdown and formation of clusters, but it is clear that in these reactions we are dealing with a whole range of equilibria in which probably all compounds are present. The product isolated depends then on the relative concentration of the species as influenced by the branching of $\mathrm{R}$ and on the solubility properties of the complexes.

A rather mysterious reaction is the virtually quantitative formation of $\left[\mathrm{Ru}_{4}(\mathrm{CO})_{8}(\mathrm{R}-\mathrm{DAB})_{2}\right]$ from $\left[\mathrm{Ru}_{2}(\mathrm{CO})_{6}(\mathrm{R}-\mathrm{DAB})\right]$ when the last compound is heated in solution without R-DAB being present [38] (see route (d) of Fig. 2). We have now obtained firm evidence for the existence of $\left[\mathrm{Ru}_{2}(\mathrm{CO})_{5}(\mathrm{R}\right.$ $\mathrm{DAB})]$ which is formed e.g. from $\left[\mathrm{Ru}_{2}(\mathrm{CO})_{6}(\mathrm{R}\right.$ $\mathrm{DAB})$ ] [42]. This reactive compound is supposed to lose another $\mathrm{CO}$ group after which dimerization leads to $\left[\mathrm{Ru}_{4}(\mathrm{CO})_{8}(\mathrm{R}-\mathrm{DAB})_{2}\right]$ [42]. The high yields of this reaction indicate a very efficient low energy pathway for the dimerization reaction.

\section{Factors Influencing the Chemical Activation of Coordinated R-DAB Groups; Formation of Binuclear Clusters}

Because of the very flexible bonding properties of R-DAB ligands, and in particular because of the ability of suitable R-DAB groups to form metal$\eta^{2}-\mathrm{C}=\mathrm{N}$ bonding, one would expect chemical activation of metal coordinated $\alpha$-diimines. In this section we will restrict ourselves to chemical activation of $\eta^{2}-\mathrm{C}=\mathrm{N}$ metal linkages. A survey of these reactions will be published in ref. [2].

\section{a. Stoichiometric $C-C$ Coupling Reactions}

Activation of the $\eta^{2} \cdot \mathrm{C}=\mathrm{N}$ bonded group is to be expected considering the $\mathrm{CN}$ bond lengthening and the strong upfield ${ }^{1} \mathrm{H}$ and ${ }^{13} \mathrm{C}$ NMR chemical shifts of the relevant atoms of the imine ${ }^{1} \mathrm{H}{ }^{13} \mathrm{C}=\mathrm{N}$ group.
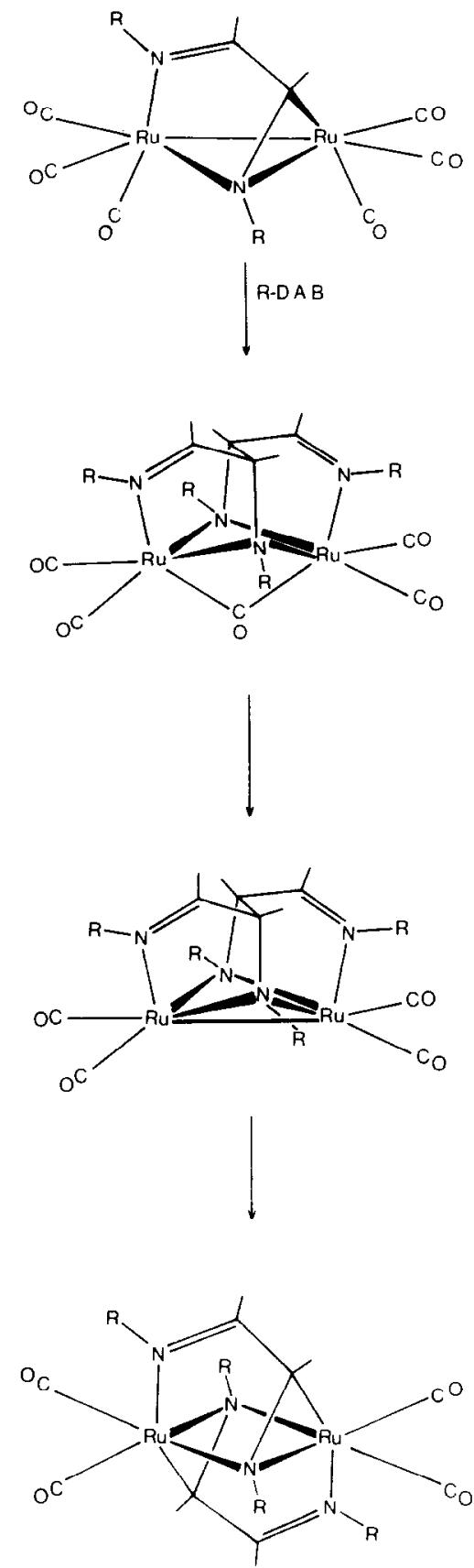

Fig. 5. Reaction of $\left[\mathrm{Ru}_{2}(\mathrm{CO})_{6}(\mathrm{R}-\mathrm{DAB})\right]$ with $\mathrm{R}-\mathrm{DAB}(\mathrm{R}=$ $\mathrm{i}-\mathrm{Pr}, \mathrm{c}-\mathrm{Hex})$ leading to $\left[\mathrm{Ru} \mathrm{u}_{2}(\mathrm{CO})_{4}(\mathrm{R}-\mathrm{DAB})_{2}\right]$ via $\left[\mathrm{Ru}_{2}\right.$ $\left.(\mathrm{CO})_{5}(\mathrm{IAE})\right](\mathrm{n}=4,5)$.

A novel reaction involves the coupling of the $\eta^{2}$. $\mathrm{C}=\mathrm{N}$ bonded group of $\left[\mathrm{Ru}_{2}(\mathrm{CO})_{6}(\mathrm{R}-\mathrm{DAB})\right]$ with R-DAB (Fig. 5) with $\mathrm{R}=\mathrm{t}-\mathrm{Bu}$, i-Pr or c-Hex [33].

In the first instance $\left[\mathrm{Ru}_{2}(\mathrm{CO})_{5}(\mathrm{IAE})\right]$ is formed (IAE $=$ bis [(alkylimino)(alkylamino)ethane $])$ which contains a $10 \mathrm{e}$ donor IAE ligand [33]. The IAE ligand consists of two $\mathrm{C}-\mathrm{C}$ coupled $\mathrm{R}-\mathrm{DAB}$ ligands. 
The $\mathrm{C}-\mathrm{C}$ coupling is completely regiospecific since the use of R-DAB $\{\mathrm{Me}, \mathrm{H}\}$ only leads to the formation of an IAE ligand in which the two R-DAB ligands are coupled through the $C$ atoms carrying the $\mathrm{H}$ substituents. Subsequent heating (for $\mathrm{R}=\mathrm{i}-\mathrm{Pr}$ and $\mathrm{c}+\mathrm{Hex}$ ) results in $\mathrm{CO}$ loss and formation of $\left[\mathrm{Ru}_{2}-\right.$ $\left.(\mathrm{CO})_{4}(\mathrm{IAE})\right]$, which contains a metal-metal bond in contrast to the $\left[\mathrm{Ru}_{2}(\mathrm{CO})_{5}(\mathrm{IAE})\right]$. Finally, further heating afforded $\left[\mathrm{Ru}_{2}(\mathrm{CO})_{4}(\mathrm{R}-\mathrm{DAB})_{2}\right]$ for which it was shown by an $\mathrm{X}$-ray structural determination for $\mathrm{R}=\mathrm{i}$-Pr that rupture had again occurred in the $\mathrm{C}-\mathrm{C}$ bond which was originally formed [33]. The reaction depends strongly on the $R$ group, since for $\mathrm{R}=\mathrm{t}-\mathrm{Bu}$ the reaction stops at $\left[\mathrm{Ru}_{2}(\mathrm{CO})_{5}(\mathrm{IAE})\right]$. Also the reaction depends on the metal since it could not be observed for $\mathrm{Fe}$, but may occur for $\mathrm{Os}$, although much more slowly.

The reaction sequence of Fig. $S$ is of interest since it clearly shows the ability of a binuclear cluster to accept or donate electrons, thereby facilitating the $\mathrm{C}-\mathrm{C}$ coupling and decoupling reactions.

Finally, it should be noted that a similar $\mathrm{C}-\mathrm{C}$ coupling reaction has been observed for Mo, resulting in the formation of $\left[\mathrm{Mo}_{2}(\mathrm{CO})_{6}(\mathrm{IAE})\right]$ [48]. Also for this case a strong dependence on $\mathrm{R}$ and on the metal could be observed. Of interest is that $\mathrm{R}-\mathrm{DAB}$ ligands may also be activated by $\mathrm{Zn}^{\mathrm{II}}, \mathrm{Al}^{\mathrm{III}}$ and $\mathrm{Mg}^{\mathrm{II}}$ alkyls leading to novel organic compounds $[22,23]$.

\section{b. Catalytic $C-C$ Coupling Reactions Involving $6 e-$ $R-D A B$ Bonded Ligands}

The reactions discussed in Section 6a led us to investigate insertion reactions of $\left[\mathrm{M}_{2}(\mathrm{CO})_{6}(\mathrm{R}-\mathrm{DAB})\right]$ with unsaturated systems such as alkynes. The multistep reactions of $\left[\mathrm{Ru}_{2}(\mathrm{CO})_{6}(\mathrm{R} \cdot \mathrm{DAB})\right](\mathrm{R}=\mathrm{iPr}, \mathrm{t}-\mathrm{Bu}$, c-Hex) with alkynes is shown in Fig. 6 for $M=R u$ [37].

The first step involves the insertion of e.g. $\mathrm{PhC}_{2} \mathrm{H}$ in the metal $-\eta^{2}-\mathrm{C}=\mathrm{N}$ bond. The crystal structure of the insertion product $\left[\mathrm{Ru}_{2}(\mathrm{CO})_{5}\left(\mathrm{t}-\mathrm{Bu}-\mathrm{DAB}-\mathrm{PhC}_{2} \mathrm{H}\right)\right]$ demonstrates that the R-DAB ligand is coupled to the $\mathrm{PhC}_{2} \mathrm{H}$ via a $\mathrm{C}-\mathrm{C}$ bond in a regiospecific way, i.e. with the $\mathrm{CPh}$ group of the alkyne to the $\mathrm{C}-\mathrm{H}$ group of $\eta^{2}-\mathrm{C}=\mathrm{N}$ bonded unit of the R-DAB ligand [37]. The $\mathrm{C}-\mathrm{C}$ bond so formed has a bond length of $1.546 \AA$. There are four terminal $\mathrm{CO}$ groups and one bridging one, while the $\mathrm{Ru}-\mathrm{Ru}$ bond is 2.711 $\AA$. The acetylenic carbon-carbon bond is reduced to $1.346 \AA$, compatible with an olefinic $\mathrm{C}=\mathrm{C}$ bond.

Further reaction of $\left[\mathrm{Ru}_{2}(\mathrm{CO})_{5}\left(\mathrm{R}-\mathrm{DAB}-\mathrm{R}^{\prime} \mathrm{C}_{2} \mathrm{H}\right)\right]$ with another alkyne afforded $\left[\mathrm{Ru}_{2}(\mathrm{CO})_{5}(\mathrm{AIB})\right.$. (alkyne)] (AIB = 3-(amino)4-(imino)-1-butene-1-yl) in which the bridging $\mathrm{CO}$ group has become terminal, while the added alkyne is bonded to one of the $\mathrm{Ru}$ atoms as a 2e-donor ligand. Subsequent heating resulted in loss of one $\mathrm{CO}$ group, while the $2 \mathrm{e}$-donor

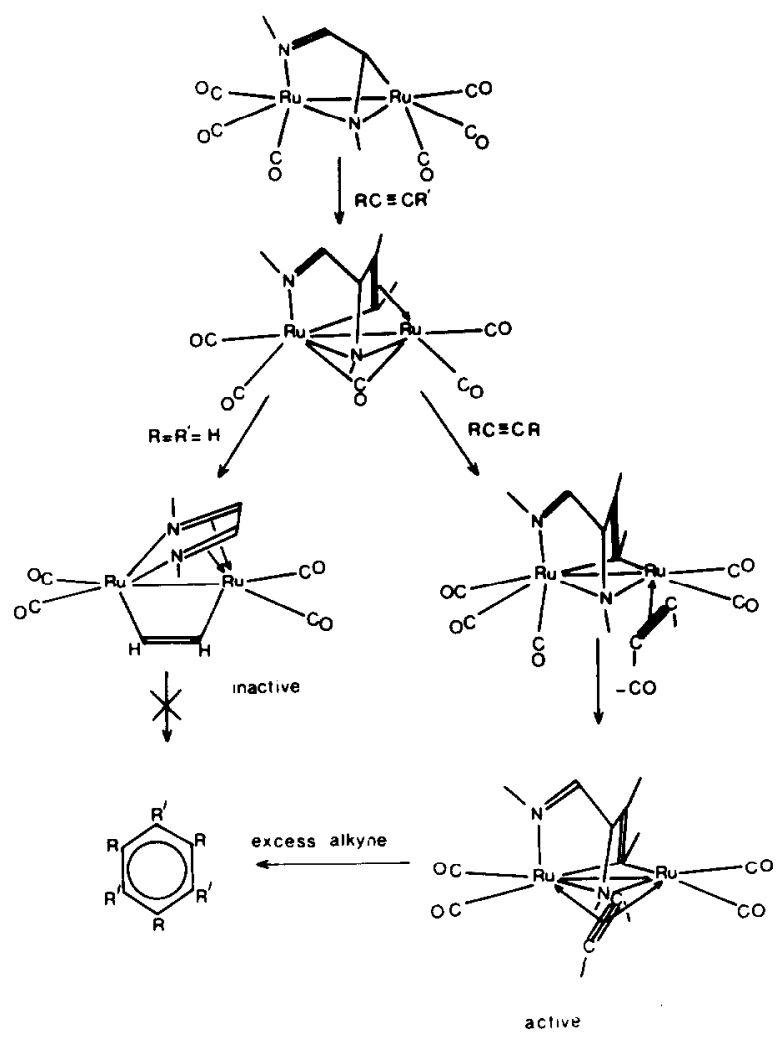

Fig. 6. Reaction of $\left[\mathrm{Ru}_{2}(\mathrm{CO})_{6}(\mathrm{R}-\mathrm{DAB})\right]$ with alkynes (see text).

alkyne changed its coordination to a 4e-bridging type of ligand.

Finally, a catalytic reaction leading to substituted benzenes occurred upon further addition of alkynes at $110^{\circ} \mathrm{C}$ [37] (Fig. 6). Interestingly, it was found that in the case of monosubstituted alkynes only 1,3,5-substituted benzenes could be obtained. This unusual stereospecificity is virtually unknown in catalytic reactions involving alkynes.

It has already been remarked that reaction of $\left[\mathrm{Ru}_{2}(\mathrm{CO})_{6}(\mathrm{R}-\mathrm{DAB})\right]$ with $\mathrm{HC}_{2} \mathrm{H}$ produced only $\left[\mathrm{Ru}_{2}(\mathrm{CO})_{4}\left(\mu^{2}-\mathrm{HC}_{2} \mathrm{H}\right)(\mathrm{R}-\mathrm{DAB})\right]$ (Section $4 \mathrm{e}$ ), which is not catalytically active.

The fact that benzenes are formed (and again only 1,3,5-substituted ones) for $\mathrm{RC}_{2} \mathrm{H}$ made us conclude that probably binuclear species are catalytically active. Furthermore, it was noted that the first two alkynes which are coordinated to the $\mathrm{Ru}_{2}$ pair are not included in the benzenes formed [37]. Finally, it is clear that again the steric factors dominate also this type of reactions, since bulky $\mathrm{R}$ groups (e.g. $\mathrm{t}-\mathrm{Bu})$ on the $\mathrm{N}$ atoms of the dimine considerably slow down the reaction. Furthermore, also the substituent on the alkyne influence the reaction rates which increase on going from elec. tron donating to electron accepting alkyne substituents. 


\section{Concluding Remarks}

It has become clear from our work on the coordination chemistry of $\alpha$-diimine ligands that the electronic and in particular the steric properties of the substituents on the diimine ligands play a prominent role in the formation of ruthenium clusters. Furthermore we have seen the importance of the substituent effects on stoichiometric and catalytic reactions being carried out on e.g. binuclear $\mathrm{Ru}_{2}$ clusters. We see therefore in this research as interesting prospects the stabilization of reactive cluster intermediates which then further react with suitable substrates to give novel compounds and reactions.

\section{References}

1 G. van Koten and K. Vrieze, Recl. Trav. Chim. Pays-Bas, 100,129 (1981).

2 G. van Koten and K. Vrieze, $A d v$. in Organometal. Chem., 1982, in press; Ed. F. G. A. Stone.

3 J. J. Keijsper, G. van Koten and K. Vriczc, unpublishcd results.

4 O. Exner and J. M. Kliegman, J. Org. Chem., 36, 2014 (1971).

5 O. Borgen, B. Mestvedt and I. Skauvic, Acta Chem. Scand., A30, 43 (1976).

6 R. Benedix, P. Birner, F. Birnstock, H. Hennig and H.-J. Hofmann, J. Mol. Struct., 51, 99 (1979).

7 I. Hargittai and R. Seip, Acta Chem. Scand., A30, 540 (1976).

8 J. Tyrell, J. Am. Chem. Soc., 101, 1766 (1979).

9 H. van der Poel, G, van Koten and K. Vrieze, Inorg. Chem., 19, 1145 (1980).

10 H. van der Poel, G. van Koten, K. Vrieze, M. W. Kokkes and C. H. Stam, Inorg. Chim. Acta, 39, 197 (1980).

$11 \mathrm{H}$. van der Poel, G. van Koten and K. Vrieze, Inorg. Chim. Acta, 51, 253 (1981).

12 H. van der Poel, G. van Koten, D. M. Grove, P. S. Pregosin and K. A. O. Starzewski, Helv. Chim. Acta, 64, 1174 (1981).

13 J. J. Keijsper, H. van der Poel, G. van Koten, K. Vrieze and C. H. Stam, Polyhedron, 1982, in press.

14 H. van der Poel, G. van Koten, M. W. Kokkes and C. H. Stam, Inorg. Chem., 20, 2491 (1981).

$15 \mathrm{H}$. van der Poel and G. van Koten, J. Organometal, Chem., 187 C17 (1980).

$16 \mathrm{H}$. van der Poel and G. Van Koten, Inorg. Chem., 20, 2950 (1981)

17 H. van der Poel, G. van Koten and G. C. van Stein, J. Chem. Soc. Dalton Trans., 2164 (1981).

$18 \mathrm{H}$. van der Poel, G. van Koten and K. Vrieze, Inorg. Chim. Acta, 51, 241 (1981).
19 H. van der Poel, G. van Koterı, K. Vrieze, M. W. Kokkes and C. H. Stam, J. Organometal. Chem., 175, C21 (1979).

20 P. Krumholz, J. Am. Chem. Soc., 75, 2163 (1953).

21 H. Arganci, C. Daul, M. Zobrist and A. von Zelewski, Helv. Chim. Acta, 58, 1732 (1975).

22 J. M. Klerks, J. T. B. H. Jastrzebski, G. van Koten and K. Vrieze, J. Organometal. Chem., 224, 107 (1982).

23 J. M. Klerks, D. J. Stufkens, G. van Koten and K. Vrieze, J. Organometal. Chem., 181, 271 (1979).

24 H. Bock and H. tom Dieck, Chem. Ber., 100, 228 (1967).

$25 \mathrm{H}$. tom Dieck and I. W. Renk, Chem. Ber, 104, 110 (1971).

26 R. W. Balk, D. J. Stufkens and A. Oskam, J. Mol. Struct., 60,387 (1980).

27 R. W. Balk, D. J. Stufkens and A. Oskam, J. Chem. Soc. Chem. Comm., 1016 (1979).

28 R. W. Balk, D. J. Stufkens and A. Oskam, Inorg.Chim. Acta, 34, 267 (1979).

29 L. H. Staal, G. van Koten and K. Vrieze, J. Organometal. Chem., 175, 73 (1979).

30 L. H. Staal, P. Bosma and K. Vrieze, Inorg. Chim. Acta, $43,125(1980)$.

$31 \mathrm{H}$. W. Frühauf, A. Landers, R. Goddard and C. Krüger, Angew. Chem., 90, 56 (1978).

32 L. H. Staal, J. J. Keijsper, G. van Koten, K. Vrieze, J. A. Cras and W. P. Bosman, Inorg. Chem., 20, 555 (1981).

33 L. H. Staal, L. H. Polm, R. W. Balk, G. van Koten, K. Vrieze and A. M. F. Brouwers, Inorg. Chem., 19, 3343 (1980).

34 L. H. Staal, G. van Koten and K. Vrieze, J. Organometal. Chem., 206, 99 (1981).

35 L. II. Staal, L. II. Polm, K. Vrieze, F. Ploeger and C. H. Stam, Inorg. Chem., 20, 1830 (1981).

36 L. H. Staal, L. H. Polm, K. Vrieze, F. Ploeger and C. H. Stam, J. Organometal. Chem., 199, C13 (1980).

37 L. H. Staal, G. van Koten, K. Vrieze, B. van Santen and C. H. Stam, Inorg. Chem., 20, 3598 (1981).

38 L. II. Staal, L. II. Polm, K. Vrieze, F. Ploeger and C. II. Stam, Inorg. Chem., 20, 3590 (1981).

39 R. D. Adams, J. Am. Chem. Soc., 102, 7476 (1980).

40 L. H. Staal, J. J. Keijsper, L. H. Polm and K. Vricze, J. Organometal. Chem., 204, 101 (1981).

41 C. H. Gast, J. C. Kraak, L. H. Staal and K. Vrieze, J. Organometal. Chem., 208, 225 (1981).

42 J. J. Keijsper, G. van Koten and K. Vrieze, to be published.

43 M. Svoboda, H. tom Dicck, C. Krüger and Y.-H. Tsay, Z. Naturforsch., 36b, 814 (1981).

44 B. Bruder, Ph.D. Thesis, Frankfurt a. Main (1979).

$45 \mathrm{H}$. tom Dieck, M. Svoboda and T. Greiser, 36b, 823 (1981).

46 M. R. Churchill, F. J. Hollander and J. P. Hutchinson, Inorg. Chem. 16, 2655 (1977).

47 K. Wade, Adv. Inorg. Radiochem., 18, 1 (1976). Acad. Press.

48 L. H. Staal, $\Lambda$. Oskam, K. Vrieze, E. Roosendaal and H. Schenk, Inorg. Chem., 18, 1634 (1979). 